\title{
The Effect of Mediation Work Engagement to Procedural Justice and Organizational Learning on the Innovative Behavior
}

\author{
Fara Kartika Sari ${ }^{\varpi}$, Palupiningdyah \\ Management Department, Faculty of Economics, Universitas Negeri Semarang, Semarang, Indonesia
}

\begin{tabular}{l} 
Article Information \\
\hline Article History: \\
Received January 2020 \\
Approved February 2020 \\
Published June 2020 \\
\hline Keywords: \\
Innovative Behavior, Pro- \\
cedural Justice, Organi- \\
zational Learning, Work \\
engagement.
\end{tabular}

\section{INTRODUCTION}

Human resources become a challenge for management, because the success of management and others depends on the quality of human resources (Ranihusna, 2013). To develop an organization to be more advanced, the organization must focus on its human resources to carry out their functions optimally, especially in the face of environmental changes that occur (Irawan \& Sudarma, 2016). The development of science and technology today requires organizations to have a competitive advantage. In order for an organization to survive facing competition, organizations need to improve the quality of their human resources (Sudarma \& Murniasih, 2016).

\begin{abstract}
The purpose of this study was to determine the effect of procedural fairness and organization learning on innovative behavior through work engagement. The population in this study were all batik craftsmen in Semarang City IKM Batik, totaling 165 . Based on this population 117 respondents were taken by proportional random sampling technique. Data collection in this study used a questionnaire, observation and interviews. The analytical method used is SPSS IBM Statistics 25 . The results innovative behavior, organizational learning can have a positive and significant effect innovative behavior and work engagement, work engagement can have a positive ant on innovative behavior, then work engagement can mediate the positive influence of procedural justice and organizational learning on innovative behavior. The conclusion of this research is procedural fairness, organizational learning ment can mediate the influence of procedural fairness and organization learning on

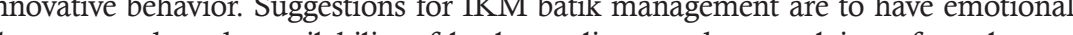
the existence of activities such as workshops and exhibitions on a regular basis to trigger increased knowledge so that it is easier to create new ideas.
\end{abstract}

Human resources have an important role either individually or in groups and human resources are one of the main drivers of the smooth running of business activities, even the progress of the company is determined by the existence of its human resources (Ghoniyah \& Masurip, 2011). Business development is currently increasing rapidly and intense competition between competitors requires companies or organizations to continue to innovate (Kusumawardani \& Nury, 2018). For this reason, organizations need to understand the factors that drive innovative employee work behavior (Amalia \& Nury, 2017).

The ability of human resources to always produce innovation, is a key factor for a business to be able to survive in conditions of intense com-

(C) 2020 Universitas Negeri Semarang

\footnotetext{
Correspondence Address:

L2 Building, 1st Floor, Faculty of Economics, Universitas Negeri Semarang

Jalan Taman Siswa, Sekaran, Gunungpati, Semarang, 50229

E-mail: ksari5499@gmail.com
} 
petition. In the industrial world, especially small and medium industries justice is very important to support the success of the organization. Motivation is the main driving behavior of a person in a job (Martono et al., 2018). In economic development in Indonesia, IKM has always been described as a sector that has an important role, because most of its employees are housewives who live in areas around the industry and have low education. One of the basic and serious problems faced by SMIs is the limited human resources (HR) owned by SMEs. Human resources owned by IKM often lack knowledge and information related to the production process, product marketing, management, and so on.

Innovative behavior plays an important role in encouraging employees' ability to innovate, because it can describe employee behavior in developing, reacting, and changing ideas (Scott \& Bruce, 2013). This is because the origins of organizational innovation come from the creative minds and innovative behaviors of employees at the individual level (Hernaus et al., 2017). Several stages in innovative behavior, which consist of introducing new problems or solutions or adaptations, seeking support for ideas and building coalitions to implement ideas, and the realization of innovative ideas and evaluating their benefits (Scott \& Bruce, 2013).

Organizational justice is found to be an important motivating factor for employees to show or not show certain behaviors. If an employee feels that he is being treated unfairly, his obligation to do work effectively can decrease and ultimately his contribution to work can also be reduced (Momeni et al., 2014). Members of the organization have an important role in human resources (Diniyati \& Ketut, 2018). The right human resource employees can create value in an organization (Martono \& Putri, 2018).

Previous studies conducted by Ramamoorthy et al. (2005) and Akram (2016) have proven that organizational procedural fairness has significant positive and direct and indirect effects on innovative work behavior by employees. However, these studies are not in line with research conducted by Almansour \& Minai (2012) found an association between organizational justice and innovative work behavior in the Jordanian government sector and found that only interactional justice has a direct and significant relationship with employees' innovative work behavior, whereas distributive and procedural justice was found to have insignificant relationship with EIWB (Employee Innovative Work Behavior).

Previous studies of organizational learning variables can also affect employee innovative behavior, according to Anders (2001) explaining that organizational learning is a form of organization that carries out the learning process in various ways and is a process of continuous change, adaptation, and learning in organizations.

Other research that states the relationship between organizational learning variables is also evidenced in research from Lin (2017) which states that organizational learning has a significant positive effect on employee innovative behavior. However, research conducted by (Kiziloglu, 2015) has the result that there is a positive relationship between organizational learning and innovation in general. It is known that there is a positive relationship between sub-factors of "commitment to learning", "shared vision" and "intra-organizational knowledge sharing" which are included in the concept of organizational learning, which determines innovation. However, it appears that there is no significant relationship between the dimensions of "open-mindedness" and innovation.

Hakanen et al. (2008) stated that individual work engagement can encourage individual initiative and subsequently can encourage innovation. Fredrickson (2001) also notes that work attachment held by employees will encourage them to feel more positive and can think creatively to explore an idea. Bakker \& Demerouti (2008) argues that with a high level of work involvement, employees can perceive their work to be more attractive, meaningful and energetic and experience positive effects that integrate joy, happiness and enthusiasm. When employees feel this is in themselves they will indirectly influence their behavior in doing a job.

\section{Hypothesis Development \\ The Effect of Procedural Justice on the Innovative Behavior}

Previous studies conducted by Akram (2016) and Ramamoorthy, et al. (2005) have proven that organizational procedural fairness has significant direct and indirect effects on employees' innovative and positive work behavior. People in organizations are very concerned about making decisions fairly, and they feel that the organization and employees will benefit equally if the organization carries out procedures fairly (Hasmarini, 2008).

Based on the literature on organizational justice by Kim \& Park (2017), the component of procedural fairness can influence innovative work behavior, which also states that the extent to which employees feel their expectations have been met (or not met) can affect their obligations to superiors.

$\mathrm{H} 1$ : Procedural justice has a positive and significant effect on innovative behavior. 


\section{Effects of Organizational Learning on Innovative Behavior}

Organizational learning plays an important role in ensuring that knowledge is always replenished and updated so as to enable work behavior that is appropriate for changes in a competitive environment (Lemon, 2004). So organizational learning is considered capable of enhancing employees' innovative behavior, because learning in organizations can increase employee knowledge so that employees are able to develop knowledge, new ideas to improve innovation.

$\mathrm{H} 2$ : Organizational learning has a positive and significant effect on innovative behavior.

\section{The Effect Of Procedural Justice On Work Enggagement}

Research on organizational justice found that employees' perceptions of procedural fairness were related to various organizational outcomes (Collquit, 2001). Measurement of how strong the impact of employees believe their work can affect the performance of the company (Wahyono et al., 2018). Procedural fair treatment by superiors, employees have assumed that the organization is like their own family (Masrukhin, 2014). More specifically, the current literature shows that organizational procedural fairness has a strong and positive impact on employee engagement both directly and indirectly (Inoue, 2010).

H3: Procedural justice has a positive and significant effect on work enggagement.

\section{Effects of Organizational Learning on Work Engagement}

Schaufeli and Bakker (2004) states that for organizations to retain workers 'knowledge and achieve goals, the importance of the values of their employees' work engagement cannot be ignored. Employees in an organization can take on work challenges and gain growth opportunities through a process of interaction experience so that employees are expected to be able to improve their individual abilities.

H4: Organizational learning has a positive and significant effect on work engagement.

\section{Effect of Work Enggagement on Innovative Behavior}

Schaufeli and Bakker (2004) stated that, work attachment is a positive mental condition and is related to work with self-realization. Further research conducted by Hakanen et al. (2008) states work engagement can improve employee personal initiatives which can further encourage innovation in the scope of work. Thus, the exis- tence of employee engagement in an organization is believed to be able to improve employee innovative behavior.

H5: Work enggagement has a positive and significant effect on innovative behavior

\section{The Effect of Mediation on Work Engagement to Procedural Justice on Innovative Behavior}

Fairness is one of the important factors that shape the individual actions of employees in the organization. This has an effect on the way employees show work behavior and work attitudes which ultimately produce positive results if treated fairly or, negatively if the opposite (Usmani \& Jamal, 2013). To perform various tasks, employees who have high self-efficacy are those who perform very well (Wuryanti \& Setiawan, 2017). Regarding the mediating effect of work engagement on the relationship between organizational procedural fairness, knowledge sharing, and innovative work behavior, the existing literature shows that if organizations are serious about caring about fairness in decision making. processes, their efforts will facilitate and support employee work engagement (Berg, 2007; Radaelli et al., 2014).

H6: Work engagement can mediate the effect of procedural fairness on innovative behavior.

\section{The Effect of Mediation on Work Engagement to Organizational Learning on Innovative Behavior}

Valle (2005) proposes that subordinates acquire, transfer, and integrate knowledge into shared knowledge in an organization and that is called organizational memory. Through an interactive process to internalize knowledge into tacit knowledge, an employee is driven by internal learning motivation so that he produces mental strength, absorption, and devotion to his work and applies it to any aspect such as products, processes, or management. In other words, an employee shows innovative behavior through this process.

From the explanation above, it can be interpreted that the higher organizational learning is carried out, it can improve the innovative behavior of employees by developing and applying the knowledge gained through learning organizations into their work if employee work engagement is also high.

H7: Work engagement can mediate the influence of learning organizations on innovative behavior.

Based on the description of the hypothesis, the research model developed is presented in Figure 1. as follows. 


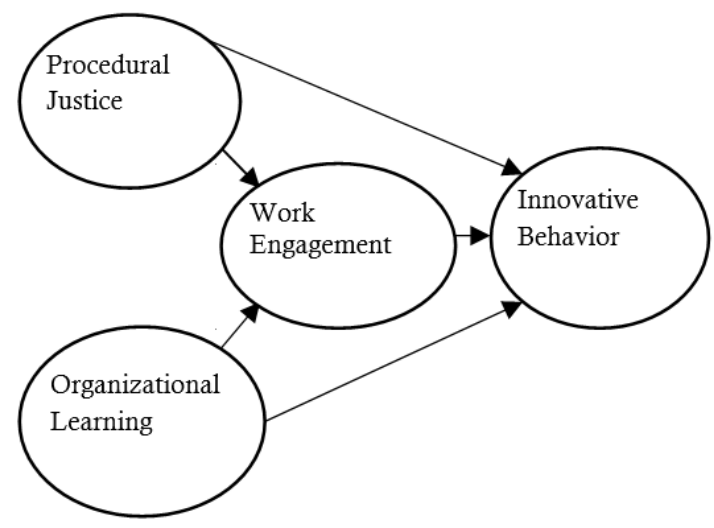

Figure 1. Research Model

\section{METHOD}

The type and design of research used in this study is quantitative research. The population in this study were 165 batik IKM batik artisans in the city of Semarang. Sampling using probability sampling techniques with proportional random sampling type thus obtained a sample size that must be used is 117 employees. This research uses four variables, namely procedural justice, learning organization, work engagement, innovative behavior . Methods of data collection can be done by interview (questionnaire), questionnaire (questionnaire), observation (observation), and a combination of the three (Sugiyono, 2016).

In this study using partial test data analysis and path analysis with the help of SPSS version 25. Data collection using a questionnaire that is measured with a Likert scale.

\section{RESULT AND DISCUSSION}

In this study, to find out the validity of an indicator then the value of $r$ is calculated. The following results of the faithful validity test of variables can be seen in table 1 .

Table 1. Test Results for the Validity of Innovative Behavior Variables

\begin{tabular}{llll}
\hline No. & $\begin{array}{l}\text { Value of } \mathbf{r} \\
\text { Calculate }\end{array}$ & $\begin{array}{l}\text { Value of } \mathbf{r} \\
\text { Table }\end{array}$ & Explanation \\
\hline 1. & 0.363 & 0.361 & Valid \\
2. & 0.388 & 0.361 & Valid \\
3. & 0.492 & 0.361 & Valid \\
4. & 0.518 & 0.361 & Valid \\
5. & 0.426 & 0.361 & Valid \\
6. & 0.498 & 0.361 & Valid \\
7. & 0.404 & 0.361 & Valid \\
8. & 0.369 & 0.361 & Valid \\
9. & 0.396 & 0.361 & Valid \\
\hline
\end{tabular}

Based on the results of the validity test of innovative behavior variables it can be seen that all questions have $r$ count values greater than $r$ tables. This means that all statements about the innovative behavior of batik artisans are declared valid.

Table 2. Test Results of Procedural Fairness Variable Validity

\begin{tabular}{llll}
\hline No. & $\begin{array}{l}\text { Value of } \mathbf{r} \\
\text { Calculate }\end{array}$ & $\begin{array}{l}\text { Value of } \mathbf{r} \\
\text { Table }\end{array}$ & Explanation \\
\hline 1. & 0.617 & 0.361 & Valid \\
2. & 0.406 & 0.361 & Valid \\
3. & 0.535 & 0.361 & Valid \\
4. & 0.284 & 0.361 & Invalid \\
5. & 0.571 & 0.361 & Valid \\
6. & 0.495 & 0.361 & Valid \\
7. & 0.542 & 0.361 & Valid \\
\hline
\end{tabular}

Based on the results of the validity test of procedural justice variables it can be seen that the question item number 6 has a $r$ count value that is smaller than $r$ table so it is not used in research.

Table 3. Validity Test Results of Organizational Learning Variables

\begin{tabular}{llll}
\hline No. & $\begin{array}{l}\text { Value of } \mathbf{r} \\
\text { Calculate }\end{array}$ & $\begin{array}{l}\text { Value of } \\
\text { r Table }\end{array}$ & Explanation \\
\hline 1. & 0.240 & 0.361 & Invalid \\
2. & 0.378 & 0.361 & Valid \\
3. & 0.527 & 0.361 & Valid \\
4. & 0.273 & 0.361 & Invalid \\
5. & 0.351 & 0.361 & Invalid \\
6. & 0.384 & 0.361 & Valid \\
7. & 0.381 & 0.361 & Valid \\
8. & 0.502 & 0.361 & Valid \\
9. & 0.678 & 0.361 & Valid \\
10. & 0.507 & 0.361 & Valid \\
11. & 0.499 & 0.361 & Valid \\
12. & 0.641 & 0.361 & Valid \\
13. & 0.539 & 0.361 & Valid \\
14. & 0.467 & 0.361 & Valid \\
15. & 0.345 & 0.361 & Invalid \\
16. & 0.251 & 0.361 & Invalid \\
17. & 0.469 & 0.361 & Valid \\
\hline
\end{tabular}

Based on the results of the test of the validity of organizational learning variables it can be 
seen the question items number $1,4,5,15$, and 16 have $r$ count values smaller than $r$ tables so they are not used in research.

Table 4. Validity Test Results of Work Engagement Variables

\begin{tabular}{llll}
\hline No. & $\begin{array}{l}\text { Value of } \mathbf{r} \\
\text { Calculate }\end{array}$ & $\begin{array}{l}\text { Value of } \\
\text { r Table }\end{array}$ & Explanation \\
\hline 1. & 0.481 & 0.361 & Valid \\
2. & 0.654 & 0.361 & Valid \\
3. & 0.509 & 0.361 & Valid \\
4. & 0.476 & 0.361 & Valid \\
5. & 0.720 & 0.361 & Valid \\
6. & 0.727 & 0.361 & Valid \\
7. & 0.628 & 0.361 & Valid \\
8. & 0.771 & 0.361 & Valid \\
9. & 0.673 & 0.361 & Valid \\
10. & 0.388 & 0.361 & Valid \\
\hline
\end{tabular}

Based on the results of the validity test of work engagement variables it can be seen that all questions have $r$ count values greater than $r$ tables. This means that all statements about work attachment are valid.

\section{Reliability Test Results}

In research, the variable is said to be reliable if the Cronbach Alpha value> 0.7. The following reliability test results are presented in table 5 .

Based on the results of the reliability test it can be seen that the indicators of the construct variable are declared reliable because the Cronbach Alpha value $>0.7$.

\section{Hypothesis Testing}

In this study a regression analysis was conducted to find out the relationship between the independent variables of procedural justice, organizational learning and work engagement on the dependent variable of innovative behavior. The hypothesis is accepted if the sig value is <sig table $(a=0.05)$. Following are the results of the direct hypothesis test presented in table 6

\section{Effect of Procedural Justice on Innovative Behavior}

The partial statistical test results of the direct effect of procedural fairness variables on innovative behavior obtained the results of $t$ test for the procedural fairness variables of 4.054 with a significance value of $0.000<0.05$, so that $\mathrm{H} 1$ is accepted.

The effort made by IKM Batik City of Semarang in providing procedural justice is by always receiving input from every craftsman before making a decision. In addition, every decision making by the head of the Semarang Batik IKM group always involves all craftsmen to avoid disputes and the craftsmen will feel treated fairly by the group leader.

The results of this study are consistent with previous studies conducted by previous studies conducted by Akram (2016) and Ramamoorthy, et al. (2005) have proven that organizational procedural fairness has significant positive and direct and indirect effects on innovative work behavior by employees.

Table 5. Reliability Test Results

\begin{tabular}{llll}
\hline No & Indicator & Cronbach's Alpha Based on Standardized Items & Explanation \\
\hline 1 & Innovative Behavior & 0.784 & Reliable \\
2 & Procedural Justice & 0.719 & Reliable \\
3 & Organizational Learning & 0.709 & Reliable \\
4 & Work Engagement & 0.707 & Reliable \\
\hline
\end{tabular}

Table 6. Direct Hypothesis Test Result

\begin{tabular}{llll}
\hline Variable & T & Sig. & Description \\
\hline Procedural Justice > Innovative Behavior & 4.054 & 0.000 & Positive, Significant \\
Organizational Leraning > Innovative Behavior & 2.033 & 0.044 & Positive, Significant \\
Procedural Justice > Work Engagement & 4.641 & 0.000 & Positive, Significant \\
Organizational Leraning > Work Engagement & 5.626 & 0.000 & Positive, Significant \\
Work Engagement > Innovative Behavior & 7.403 & 0.000 & Positive, Significant \\
\hline Sources: Primary data is processed (2019) & & &
\end{tabular}




\section{Effects of Organizational Learning on Innovative Behavior}

The partial statistical test results of the direct effect of procedural fairness variables on innovative behavior obtained by testing the value of $t$ calculated for procedural justice variables of 2.033 with a significance value of $0.044<0.05$, so $\mathrm{H} 2$ is accepted.

Efforts made by IKM Batik Semarang City in increasing knowledge through organizational learning is by involving the craftsmen in a series of activities held by the industry service such as a workshop on batik. This is done with the aim that the craftsmen have a new perspective on batik and can find new ideas to improve the quality of batik at the Semarang City IKM Batik. In addition, the head of the group in IKM Batik also involved batik craftsmen to take part in batik exhibitions both inside and outside the city with the aim of the craftsmen to exchange knowledge with other craftsmen about batik.

The results of this study are consistent with previous research conducted by previous research conducted by Lin (2017) which states that organizational learning has a significant positive effect on employees' innovative behavior. In organizations there are many members who have sufficient knowledge and skills to solve the problems faced (Yuniawan Ahyar et al., 2017). So it is proven that organizational learning provided by the organization can improve employee innovative behavior. In addition, this study also supports the results of research conducted by Park et al. (2014) which states that organizational learning positively influences innovative behavior..

\section{Effect of Procedural Justice on Work Enggagement}

The partial statistical test results of the direct effect of procedural fairness variables on innovative behavior obtained the test results of the calculated $t$ value for procedural justice variables of 4.641 with a significance value of $0.000<0.05$, so that $\mathrm{H} 3$ is accepted.

The efforts made by IKM Batik Kota Semarang in increasing procedural fairness in influencing the work engagement of craftsmen are by always involving every activity held by the industry service so that employees feel involved and feel comfortable in doing every work given by the group leader. So that the craftsmen are more enthusiastic in carrying out work every day.

The results of this study are consistent with previous studies conducted by previous studies conducted by Karatepe (2011) who stated that procedural justice positively influences work engagement. So it is proven that procedural fairness given to craftsmen will increase the work engagement of the craftsmen themselves. In addition this study also supports previous research conducted by Raharjo et al., (2016) which states that procedural justice has a positive effect on work engagement

\section{Effects of Organizational Learning on Work Engagement}

The partial statistical test results of the direct influence of organizational learning variables on work engagement obtained the test results of the $t$ value for organizational learning variables of 5.626 with a significance value of $0.000<0.05$, so that $\mathrm{H} 4$ is accepted.

Efforts made by IKM Batik Semarang to improve organizational learning in influencing the work engagement of artisans are by involving the craftsmen in every activity held by the industry service and batik IKM itself so that employees are more enthusiastic, dedicated, and focused on the goals of Semarang batik IKM.

The results of this study are consistent with previous studies conducted by previous research conducted by Anwar, (2017) which states that Organizational Learning has a positive effect on work engagement. This means that every activity carried out by the craftsmen is able to increase the enthusiasm, dedication and focus of the batik craftsmen of IKM Batik Semarang.

\section{Effect of Work Attachment on Innovative Behavior}

The partial statistical test results of the direct influence of procedural fairness variables on innovative behavior obtained the results of $t$ test for the procedural justice variables of 7.403 with a significance value of $0.000<0.05$, so that H5 is accepted.

Efforts made by IKM Batik Kota Semarang in maintaining attachment Efforts made by IKM Batik Kota Semarang in maintaining employee engagement are by continuing to provide an opportunity for opinion for every craftsman as well as encouraging / encouraging the craftsmen to be more daring to experiment in creating new ideas such as creating new motives to improve the quality of batik.

The results of this study are in accordance with previous studies conducted by previous research conducted by Ariyani \& Hidayati (2018) which states that work attachment has a positive and significant effect on innovative behavior. So that if the craftsman feels himself bound in doing his work which makes the craftsman more 
enthusiastic, dedicated, and focused on the work it can increase employees' innovative behavior in generating new innovations.

\section{Sobel Test}

The sobel test is carried out by testing the strength of the indirect effect of the independent variable $(\mathrm{X})$ on the dependent variable $(\mathrm{Y})$ through the mediating variable $(\mathrm{M})$. Determination of the acceptance of the effect of mediation is seen by comparing the $t$ value and $t$ table value. If the value of $t$ arithmetic is greater than $t$ table $(t$ arithmetic $>1.960$ ) then it can be concluded that there is a mediating effect. The following formula uses the sobel test.

$$
\mathrm{S}_{\mathrm{ab}}=\sqrt{ }\left(\mathrm{b}^{\wedge}(2) \llbracket \mathrm{Sa} \rrbracket^{\wedge} 2\right)+\mathrm{a}^{\wedge} 2 \llbracket \mathrm{Sb} \rrbracket^{\wedge} 2+
$$
$\llbracket \mathrm{Sa} \rrbracket^{\wedge} 2 \llbracket \mathrm{Sb} \rrbracket^{\wedge} 2$

\section{Effect of Procedural Justice on Innovative Behavior through Work Engagement} $\llbracket \mathrm{Sb} \rrbracket \wedge 2)$

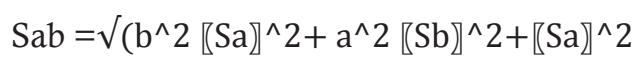

$$
=\sqrt{ }\left((0,547)^{\wedge}(2) \llbracket(0,074) \rrbracket^{\wedge}(2)+\llbracket(0,353)\right.
$$

$\rrbracket^{\wedge}(2) \quad \llbracket(0,069) \rrbracket^{\wedge}(2)+\llbracket(0,074) \rrbracket^{\wedge}(2) \quad \llbracket(0,069)$ $\left.\rrbracket^{\wedge}(2)\right)$

$$
=0,047
$$$$
=\mathrm{ab} / \mathrm{Sab}=0,193 / 0,047=4,106
$$

$\mathrm{t}$ arithmetic $=4,106>\mathrm{t}$ table $=1,960$

Based on the results of manual calculations obtained $t$ count of 4.106 . This value is greater than $\mathrm{t}$ table that is $1,960(\mathrm{t}$ arithmetic $=$ $4.106>t$ table $=1.960$ ) so it can be concluded that $\mathrm{H} 6$ is accepted.

The efforts made by IKM Batik Kota Semarang in increasing procedural fairness in influencing the work engagement of craftsmen are by always involving every activity held by the industry service so that employees feel involved and feel comfortable in doing every work given by the group leader. So that the craftsmen are more enthusiastic in carrying out work every day.

The results of this study are consistent with previous studies conducted by previous studies conducted by Karatepe (2011) who stated that procedural justice positively influences work engagement. So it is proven that procedural fairness given to craftsmen will increase the work engagement of the craftsmen themselves. In addition this study also supports previous research conducted by Raharjo et al., (2016) which states that procedural justice has a positive effect on work engagement.

\section{Effects of Organizational Learning on Innovative Behavior through Work Engagement}

$$
\begin{aligned}
& =\sqrt{ }\left(\left((0,547)^{\wedge}(2) \quad(0,066)^{\wedge}(2)\right)+\right. \\
& (0,428)^{\wedge}(2)(0,069)^{\wedge}(2) @+\llbracket(0,066) \rrbracket^{\wedge}(2) \\
& \left.\left.\llbracket(0,069) \rrbracket^{\wedge}(2)\right)\right) \\
& =0,046 \\
& \mathrm{t}=\mathrm{ab} / \mathrm{Sab}=0,234 / 0,046=5,282 \\
& \mathrm{t} \text { arithmetic }=4,106>\mathrm{t} \text { table }=1,960
\end{aligned}
$$

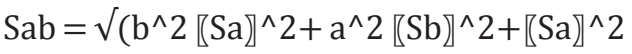

Based on the results of manual calculations obtained t count of 5.282. This value is greater than $\mathrm{t}$ table that is 1.9809 ( $\mathrm{t}$ count $=5.282>$ $\mathrm{t}$ table $=1.960)$ so it can be concluded that $\mathrm{H} 7$ is accepted.

Efforts made by IKM Batik Semarang to improve organizational learning in influencing the work engagement of artisans are by involving the craftsmen in every activity held by the industry service and batik IKM itself so that employees are more enthusiastic, dedicated, and focused on the goals of Semarang batik IKM.

The results of this study are in accordance with previous studies conducted by previous research conducted by Anwar, (2017) which states that Organizational Learning has a positive effect on work engagement. This means that every activity carried out by the craftsmen is able to increase the enthusiasm, dedication, and focus of the batik craftsmen of IKM Batik Semarang.

\section{CONCLUSION AND RECOMMENDATION}

Based on data analysis and discussion of research results, it can be concluded that procedural fairness and organizational learning can improve innovative behavior of Semarang batik SMI batik craftsmen. This also affects work engagement, the higher the procedural fairness provided by the chairperson and the better organizational learning in the workplace will indirectly increase the work engagement of the batik craftsmen themselves.

Future research is expected to explore procedural fairness and organizational learning that still needs to be done research on the same aspects to test the consistency of the results of this study.

\section{REFERENCES}

Akram, T. (2016). The Effects of Organizational Justice on the Innovative Work Behavior of Employees: An Empirical Study from China, Journal of Creativity and Business Innovation (2), 
(November).

Almansour, Y. M., \& Minai, M. S. (2012). The Relationship between Organizational Justice Components and Innovative Behavior in Arab Society. Evidence from Government Department in Jordan. Middle-East journal of scientific research 12(1), 46-51.

Amalia, SR (2017). Effect of Person Organization Fit on Innovative Work Behavior Empowerment through Mediation on Employee Psychological as KSPPS in Semarang. Management Analysis Journal,6 (2).

Anders, O. (2001). On differences between Organizational Learning and Learning Organization, 8(3), 125-133.

Bakker, A. B., \& Demerouti, E. (2008). Towards a Model of Work Engagement, 13(3), 209-223.

Schepers, P., \& Van Den Berg, P. T. (2007). Social Factors of Work-Environment Creativity. Journal of Business and Psychology, 21(3), 407-428.

Colquitt, J. A., Conlon, D. E., Wesson, M. J., \& Porter, C. O. L. H. (2001). Justice at the Millennium: A Meta-Analytic Review of 25 Years of Organizational Justice Research. Journal of Applied Psychology. 86.(3), 425-445.

Diniyati,Lia. \& Sudarma. (2018). The Effect of Meaning of Work and Psychological Empowerment on Affective Commitment with Work Engagement as an Intervening Variable. Management Analysis Journal, 7(2).

Fredrickson, B. L. (2001). The Role of Positive Emotions in Positive Psychology: The BroadenAnd-Build Theory of Positive Emotions. American Psychologist, 56(3), 218.

Ghoniyah, N., \& Masurip. (2011). Peningkatan Kinerja Karyawan melalui Kepemimpinan, Lingkungan Kerja dan Komitmen. Jurnal Dinamika Manajemen, 2(2), 118-129.

Hakanen, J. J., Perhoniemi, R., \& Toppinen-Tanner, S. (2008). Positive Gain Spirals at Work: From Job Resources to Work Engagement, Personal Initiative and Work-Unit Innovativeness. Journal of Vocational Behavior, 73(1), 78-91.

Hasmarini, D. P. (2008). Pengaruh Keadilan Prosedural dan Distributif terhadap Kepuasan Kerja dan Komitmen Afektif. Jurnal Bisnis Strategi, 17(1), 99-118.

Hernaus, T., Dysvik, A., \& Behaviour, O. (2017). The Role of Multilevel Synergistic Interplay among Team Mastery Climate, Knowledge Hiding, and Job Characteristics in Stimulating Innovative Work Behavior. Human Resource Management Journal 27(2), 281-299.

Inoue, A., Kawakami, N., Ishizaki, M., Shimazu, A., Tsuchiya, M., Tabata, M., Akiyama, M., Kitazume, A., \& Kuroda, M. (2010). Organizational Justice, Psychological Distress, and Work Engagement in Japanese Workers. International Archives of Occupational and Environmental Health, 83(1), 29-38.

Irawan, L., Sudarma, K., Manajemen, J., Ekonomi, F., Semarang, U. N., \& Artikel, I. (2016). Penga- ruh Keadilan Distributif dan Keadilan Prosedural pada Komitmen Afektif melalui Kepuasan Kerja. Management Analysis Journal, 5(2), 149-155.

Kiziloglu, M. (2015). The Effect of Organizational Learning on Firm Innovation Capability : An Investigation in the Banking Sector. Global Business and Management Research, 7(3), 17-33.

Kusumawardani, D., \& Wulansari, N. A. (2018). The Effect of Humors and Narcissistic Personality on the Innovative Output with Innovative Work Behavior and Adaptability as Variables of Mediation. Management Analysis Journal, 7(3), 352-362.

Lin, H. (2017). A Study of the Influence of Organizational Learning on Employees' Innovative Behavior and Work Engagement by a Cross-Level Examination. Eurasia Journal of Mathematics, Science and Technology Education, 13(7), 34633478.

Martono, S., \& Wulansari, N. A. (2018). Remuneration Reward Management System as a Driven Factor of Employee Performance. International Journal of Business and Society, 19, 535-545.

Martono, S., \& Putri, V. W. (2018). HRM Practices in Indonesia: The Contributing Power of Embeddedness and Support. Jurnal Dinamika Manajemen, 9(2), 206-217.

Momeni, M., Ebrahimpour, D. H., \& Ajirloo, D. M. B. (2014). Surveying the Impact of Inferential Organizational Justice on Innovative Work Behavior. Singapore an Journal of Business Economics and Management Studies, 2 (9).

Radaelli, G., Lettieri, E., Mura, M., \& Spiller, N. (2014). Knowledge Sharing and Innovative Work Behaviour in Healthcare: A Micro-Level Investigation of Direct and Indirect Effects. Creativity and Innovation Management, 23(4), 400-414.

Raharjo, D. C., Witiastuti, R. S., Manajemen, J., Ekonomi, F., Semarang, U. N., \& Artikel, I. (2016). Variabel Mediasi, 5(4), 347-361.

Ramamoorthy, N., Flood, P. C., Slattery, T., \& Sardessai, R. (2005). Determinants of Innovative Work Behaviour: Development and Test of an Integrated Model. Creativity and Innovation Management, 14(2), 142-150.

Ranihusna, D. (2013). Efek Rantai Motivasi pada Kinerja Karyawan. Jurnal Dinamika Manajemen, 1(2), 90-103.

Scott, S. G., Bruce, R. A., Scott, S. G., \& Bruce, R. A. (2013). Determinants of Innovative Behavior: A Path Model of Individual Innovation in the Workplace. Academy of Management Journal, 37(3), 580-607.

Sudarma, K., \& Murniasih, E. (2016). Pengaruh Persepsi Dukungan Organisasi dan Kompensasi pada Kinerja Karyawan Dimediasi Komitmen Afektif. Management Analysis Journal, 5(1), 24-35.

Sugiyono. (2011). Metode Penelitian Pendidikan Pendekatan Kuantitatif, Kualitatif, dan $R \& D$. Bandung: Alfabeta. 
Jerez-Gomez, P., Cespedes-Lorente, J., \& Valle-Cabrera, R. (2005). Organizational Learning Capability: A Proposal of Measurement. Journal of Business Research, 58(6), 715-725.

Wahyono, W., Prihandono, D., \& Wijayanto, A. (2018). Behavioural Assessment Perspective on Reward System Management and Performance: An Empirical Finding on Indonesian Lecturer. Jurnal Dinamika Manajemen, 9(1), 80-88.

Wuryanti, W., \& Setiawan, I. (2017). A Model for Im- proving Human Resource Performance in the Context of Knowledge Donating. Jurnal Dinamika Manajemen, 8(2), 208-215.

Yuniawan, A., daughter, VW, and Udin (2017). Developing an Alternative Model for the Relationship Among Social Capital, Adaptive-Integrative Leadership, Competitive Advantage, and Organizational Effectiveness. International Journal of Civil Engineering and Technology, 8(11), $52-60$. 